\title{
Primary sudden onset severe headache: Prognosis and factors influencing it
}

\author{
BK Kim \\ From The European Headache and Migraine Trust International Congress \\ London, UK. 20-23 September 2012
}

\section{Introduction}

Sudden onset severe headache, so called thunderclap headache, is a common condition that sometimes indicates a life-threatening conditions such as subarachnoid haemorrhage (SAH). Little is known about the prognosis of primary sudden onset severe headache (PSOH). Objectives To investigate the recurrence rate of sudden onset severe headache with normal brain imaging and lumbar puncture and factors associated with its recurrence.

\section{Methods}

We have performed a prospective study of 80 consecutive patients with $\mathrm{PSOH}$. PSOH was defined as reaching maximum intensity (visual analogue scale 27 ) within a few seconds with normal CSF and brain imaging. We investigate recurrence rate of $\mathrm{PSOH}$ and prognostic factors associated with its recurrence: sex, age, provoking factors, etc.

\section{Results}

Mean age was 45 years (15-70) and female was $62 \%$. Mean follow up duration was 504 days $(\mathrm{SD}=272$ days, ranged from 2 to 30 months) from first visit. 43 patients with $\mathrm{PSOH}$ experienced at least two attacks. Recurrence of PSOH after 1st visit occurred in 15 cases. Nine out of 15 patients experienced recurrence within two weeks. Six patients experienced recurrence three month after first visit. All factors examined including age, sex, provoking factors, severity of headache, number of attacks at first visit, history of other primary headache and presence of reversible cerebral vasoconstriction syndrome were not associated with recurrence of $\mathrm{PSOH}$.

\section{Conclusion}

We observed that the recurrence of $\mathrm{PSOH}$ after one month is not common. Recurrence usually occurred within 2 weeks after first visit.

Published: 21 February 2013

\section{Reference}

1. Linn FH, Rinkel GJ, Algra A, van Gijn J: Follow-up of idiopathic thunderclap headache in general practice. J Neurol 1999, 246:946-8.

doi:10.1186/1129-2377-14-S1-P133

Cite this article as: Kim: Primary sudden onset severe headache: Prognosis and factors influencing it. The Journal of Headache and Pain 2013 14(Suppl 1):P133.
Submit your manuscript to a SpringerOpen ${ }^{\bullet}$ journal and benefit from:

- Convenient online submission

- Rigorous peer review

- Immediate publication on acceptance

Open access: articles freely available online

- High visibility within the field

- Retaining the copyright to your article

\section{SpringerOpen ${ }^{\circ}$}

(c) 2013 Kim; licensee Springer. This is an Open Access article distributed under the terms of the Creative Commons Attribution License (http://creativecommons.org/licenses/by/2.0), which permits unrestricted use, distribution, and reproduction in any medium, provided the original work is properly cited. 